\title{
Uji adaptasi sorgum (Sorghum bicolor) berdaya hasil tinggi di wilayah Kediri
}

\section{Adaptation test of high yield sorghum in Kediri}

\author{
Retno Dwi Andayani \\ Dosen Program Studi Agroteknologi, Fakultas Pertanian, Universitas Islam Kadiri \\ Jalan Sersan Suharmaji no 38 Kota Kediri, 64138 \\ *Email korespondensi : retnodwiandayani@yahoo.co.id \\ Diterima: 18 September 2020 / Disetuji: 22 Maret 2021
}

\begin{abstract}
The objective of research was to determine the growth and yield of three sorghum varieties in Kediri. This research was implemented on June-September 2019 at Agriculture Integrated Field Laboratory, UNISKA, Kediri with altitude 46 meters above sea level, <5\% slope, alluvial soil with sandy clay structure. This research used Randomized Block Design, single factor of three sorghum varieties (Kawali, Numbu and Suri 4). Result represented that growth and yield had a significant effect. All varieties grow well under drought condition in Kediri, but only Numbu and Suri 4 are able to provide maximum yield.
\end{abstract}

Keywords: sorghum, high yield, drought, marginal soil

\section{ABSTRAK}

Tujuan penelitian ini adalah untuk mengetahui pertumbuhan dan hasil tiga varietas sorgum di Wilayah Kediri. Penelitian dilaksanakan di Laboratorium Lapang Terpadu Fakultas Pertanian UNISKA Kota Kediri dengan ketinggian tempat 46 mdpl, kemiringan lahan <5\% dan jenis tanah aluvial berstruktur lempung berpasir pada bulan Juni-September 2019. Penelitian menggunakan Rancangan Acak Kelompok dengan faktor 3 jenis varietas sorgum yaitu Kawali, Numbu dan Suri 4. Hasil penelitian menunjukkan komponen pertumbuhan dan hasil yang berpengaruh nyata. Ketiga varietas dapat tumbuh dengan baik dalam kondisi cekaman kering di Wilayah Kediri, namun hanya varietas Numbu dan Suri 4 yang mampu memberikan hasil yang maksimal.

Kata kunci: sorgum, daya hasil tinggi, lahan kering

\section{PENDAHULUAN}

Kebutuhan akan beras sebagai bahan pangan utama Indonesia cenderung terus meningkat setiap tahunnya seiring dengan peningkatan jumlah penduduk. Pada tahun 2025 penduduk Indonesia diprediksi mencapai lebih kurang 300 juta jiwa yang tentunya akan membutuhkan beras dalam jumlah yang sangat besar. Selama ini, peningkatan produksi beras nasional sangat tergantung pada padi sawah, sementara luas lahan sawah cenderung terus menyusut akibat alih fungsi penggunaan untuk usaha non-pertanian. Kondisi semacam itu akan mempersulit Indonesia untuk dapat memenuhi kebutuhan beras secara mandiri jika hanya mengandalkan pada produksi padi lahan sawah (Human, 2011).

Sebagai alternatif yang dapat ditempuh adalah dengan meningkatkan produktivitas tanaman penghasil karbohidrat non-beras di lahan kering. Indonesia memiliki potensi yang sangat besar untuk memproduksi karbohidrat dari tanaman. Keanekaragaman jenis tanaman yang potensial sebagai sumber pangan tumbuh subur dan tersebar luas di wilayah Indonesia salah satunya sorgum (Elizabeth, 2011).

Sorgum adalah tanaman serbaguna yang dapat digunakan sebagai sumber pangan, pakan ternak dan bahan baku industri. Sebagai bahan pangan, sorgum berada pada urutan ke-5 setelah gandum, jagung, padi dan jelai (Ariani, M \& Ashari, 2003). Namun dalam roadmap pengembangan dan penyediaan pangan nasional, sorgum jarang diungkapkan secara eksplisit sebagai bagian integral dari pangan pokok nasional. Menurut Subagio et al. (2014) fakta lapangan menunjukkan bahwa walaupun tanaman sorgum sudah lama dikenal petani, namun masih diusahakan secara asal karena dipandang sebagai tanaman kelas rendah.

Walaupun dianggap sebelah mata, sorgum memiliki beberapa keunggulan. Sorgum merupakan tanaman pangan yang adaptif dan sesuai dikembangkan di wilayah tropis. Sebagai tanaman golongan $\mathrm{C} 4$, sorgum efisien dalam menghasilkan produk fotosintesis yang tinggi. Suhu optimum untuk pertumbuhan tanaman sorgum berkisar antara $21-35^{\circ} \mathrm{C}$ dengan kisaran suhu tanah minimum 15 $18^{\circ} \mathrm{C}$. Secara agronomis, sorgum mempunyai kelebihan, di 
antaranya toleran kekeringan, kadar garam tinggi, dan daya adaptasi yang luas. Umur panen tanaman sorgum adalah 3-4 bulan, kebutuhan air per musim $4.000 \mathrm{~m}^{3}$, lebih rendah dibandingkan dengan jagung dan tebu yang membutuhkan air masing-masing $8.000 \mathrm{~m}^{3}$ dan $36.000 \mathrm{~m}^{3}$ (Ariani, M \& Ashari ,2003).

Toleransi sorgum terhadap kekeringan dipengaruhi oleh sistem perakaran tanaman, karakteristik daun, dan pengaturan osmotik. Sorgum memiliki akar yang lebat, ekstensif, dan bercabang sehingga apabila terjadi kekeringan, perakaran cepat menyerap air dan tersedia bagi tanaman, ditandai oleh peningkatan nilai potensial air tanaman, sehingga recovery berlangsung lebih cepat. Selain itu, akar sorgum mampu tumbuh lebih dalam sampai kedalaman 120-180 cm apabila terjadi cekaman kekeringan. Tanaman sorgum memilki sifat lebih toleran terhadap keracunan Al, salinitas tinggi, dan genangan air dibanding tanaman tebu dan serealia lain. Sorgum juga memerlukan pupuk relatif lebih sedikit dan pemeliharaannya lebih mudah (Sirappa, 2003).

Dari berbagai karakteristik tanaman sorgum, maka besar kemungkinan sorgum akan sesuai untuk ditanam di lahan kering dan marginal yang banyak terdapat di Wilayah Kediri. Selain mendukung program diversifikasi pangan, penanaman sorgum juga akan mengoptimalkan lahan marginal. Namun tidak semua jenis sorgum bisa sesuai dengan wilayah Kediri, sehingga perlu adanya seleksi terhadap jenis sorgum yang mampu beradaptasi dan berdaya hasil tinggi di Wilayah Kediri.

\section{BAHAN DAN METODE}

Penelitian ini dilaksanakan di Laboratorium Lapang Terpadu Fakultas Pertanian UNISKA di Desa Rejomulyo Kota Kediri. Penelitian ini dilaksanakan selama 5 bulan dimulai bulan Juni-November 2019.

\section{Alat dan Bahan}

Bahan yang digunakan adalah 3 jenis varietas sorgum yaitu Kawali, Numbu dan Suri 4. Bahan lain yang digunakan adalah pupuk kandang ayam, furadan dan pupuk NPK. Alat yang digunakan adalah alat standar budidaya tanaman, alat ukur standar (alat ukur berat dan panjang) serta perlengkapan dokumentasi.

\section{Rancangan Percobaan}

Penelitian ini disusun berdasarkan Rancangan Acak Kelompok dengan 7 ulangan. Faktor adalah 3 varietas sorgum yaitu Kawali, Numbu dan Suri 4. Jika ada perbedaan maka hasil analisis varian akan di uji lanjut dengan menggunakan BNT. Parameter yang diamati adalah daya tumbuh (\%), tinggi tanaman (cm), jumlah daun (helai), umur berbunga (hst), umur panen (hst), berat 1000 biji (g), panjang malai $(\mathrm{cm})$, berat malai $(\mathrm{g})$, berat biji per tanaman (g) dan potensi hasil (ton ha ${ }^{-1}$ ).

\section{HASIL DAN PEMBAHASAN}

Hasil analisis data secara statistik menunjukkan perbedaan yang nyata pada hampir semua parameter yang diamati pada Varietas Kawali, Numbu dan Suri 4 kecuali pada jumlah daun.

Persentase tumbuh menunjukkan kebernasan benih yang ditanam. Seluruh varietas yang ditanam memiliki persentase daya tumbuh lebih dari $75 \%$. Jika dibandingkan dengan peraturan pemerintah untuk daya tumbuh minimal golongan serealia adalah $80 \%$, maka daya tumbuh Varietas Kawali yang ditanam di Wilayah Kediri masih dibawah standar (Tabel 1).

Dari ketiga varietas yang ditanam, varietas yang memiliki daya tumbuh yang baik adalah varietas Suri 4 dan Numbu dengan persentase daya tumbuh lebih dari $80 \%$. Namun persentase daya tumbuh ini memang lebih tinggi jika dibandingkan penelitian lain dengan menggunakan varietas yang sama.

Menurut Fikri, et al. (2015) persentase daya tumbuh untuk Varietas Kawali hanya sebesar $62,67 \%$, jauh lebih rendah dibandingkan dengan hasil penelitian ini. Berbagai hal dapat berpengaruh terhadap persentase daya tumbuh benih antara lain, mutu fisik benih, mutu fisiologis benih, kesesuaian lahan serta ketersediaan air pada fase perkecambahan.

Pengamatan tinggi tanaman memiliki hasil yang berbeda nyata (Tabel 1). Dari ketiga varietas sorgum yang ditanam, seluruhnya memiliki tinggi tanaman di atas 170 $\mathrm{cm}$. Varietas Kawali dan Suri 4 memiliki tinggi tanaman yang paling tinggi dibandingkan dengan Varietas Numbu. Hal ini sesuai dengan deskripsi dari masing-masing varietas (Balitsereal, 2017). Jika dibandingkan dengan hasil deskripsi, tinggi tanaman Varietas Kawali dan Numbu sesuai dengan deskripsi yang dituliskan. Hal ini berarti bahwa varietas tersebut mampu tumbuh dengan baik di Wilayah Kediri. Sedangkan untuk tinggi tanaman Varietas Suri 4 masih jauh di bawah deskripsi varietas dengan selisih hampir $40 \mathrm{~cm}$. Sehingga perlu pengamatan lebih lanjut apa yang menyebabkan tinggi tanaman Varietas Suri tidak sesuai dengan deskripsi.

Pengamatan jumlah daun menunjukkan hasil yang tidak berbeda nyata (Tabel 1). Jika dilihat dari rerata masing-masing varietas, jumlah daun yang dihasilkan sesuai dengan deskripsi varietas yaitu kurang lebih 15 helai. Pengamatan jumlah daun penting untuk dilakukan sebagai patokan untuk mengetahui kemampuan tanaman dalam menghasilkan fotosintat. Fotosisntat digunakan sebagai bahan baku untuk seluruh proses dalam tanaman. Semakin besar fotosintat yang dihasilkan maka akan semakin besar pula produktivitas tanaman.

Pengamatan umur berbunga pada tiga varietas menunjukkan pengaruh yang nyata. Varietas yang paling cepat berbunga adalah Varietas Suri 4, selanjutnya Varietas Numbu dan yang paling lama adalah Varietas Kawali. 
Tabel 1. Hasil Analisis Parameter Pertumbuhan

\begin{tabular}{|c|c|c|c|c|c|c|}
\hline Varietas & $\begin{array}{c}\text { Daya tumbuh } \\
(\%) \\
\end{array}$ & $\begin{array}{l}\text { Tinggi Tan } \\
(\mathrm{cm})\end{array}$ & $\sum$ daun (helai) & $\begin{array}{c}\text { Umur Berbunga } \\
\text { (hst) }\end{array}$ & Umur $\mathrm{Pa}$ & nen (hst) \\
\hline Kawali & $78,571 \quad \mathrm{a}$ & $187,648 \quad a b$ & 15,481 & $71,000 \quad \mathrm{c}$ & 103,429 & $\mathrm{~b}$ \\
\hline Suri 4 & 81,714 & 195,498 & 15,586 & 68,286 & 96,857 & $\mathrm{a}$ \\
\hline Numbu & 85,571 & 178,821 & 15,366 & 56,143 & 102,000 & $\mathrm{~b}$ \\
\hline BNT & 3,967 & 11,921 & tn & 0,849 & 2,9 & 96 \\
\hline
\end{tabular}

'* Berdasarkan uji Beda Nyata Terkecil 5\%

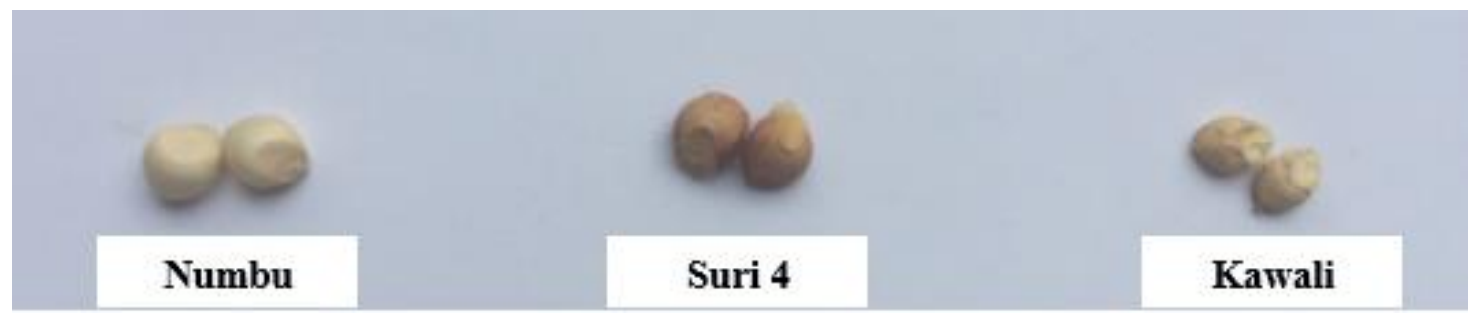

Gambar 1. Benih varietas Numbu, Suri 4 dan Kawali

Tabel 2. Hasil Analisis Parameter Panen

\begin{tabular}{|c|c|c|c|c|c|c|c|c|c|c|}
\hline \multirow{2}{*}{$\begin{array}{l}\text { Varietas } \\
\text { Kawali }\end{array}$} & \multicolumn{2}{|c|}{$\begin{array}{c}\text { Berat } 1000 \text { biji } \\
(\mathrm{g}) \\
\end{array}$} & \multicolumn{2}{|c|}{$\begin{array}{l}\text { Panjang malai } \\
(\mathrm{cm})\end{array}$} & \multicolumn{2}{|c|}{ Berat malai $(\mathrm{g})$} & \multicolumn{2}{|c|}{$\begin{array}{c}\text { Berat biji per tan } \\
(\mathrm{g})\end{array}$} & \multicolumn{2}{|c|}{ Potensi hasil (ton/ha) } \\
\hline & 31,300 & $\mathrm{~b}$ & 27,780 & $\mathrm{~b}$ & 86,437 & $\mathrm{a}$ & 80.647 & $\mathrm{a}$ & 5,242 & $\mathrm{a}$ \\
\hline Suri 4 & 28,877 & $\mathrm{a}$ & 29,100 & $\mathrm{c}$ & 93,926 & $\mathrm{~b}$ & 87,900 & $\mathrm{c}$ & 5,714 & $\mathrm{c}$ \\
\hline Numbu & 43,607 & $\mathrm{c}$ & 26,314 & $\mathrm{a}$ & 92,887 & $\mathrm{~b}$ & 86,447 & $\mathrm{~b}$ & 5,619 & $\mathrm{~b}$ \\
\hline $\mathrm{BNT}$ & 2,996 & & 0,856 & & 1,065 & & 1,068 & & & 059 \\
\hline
\end{tabular}

'* Berdasarkan uji Beda Nyata Terkecil 5\%

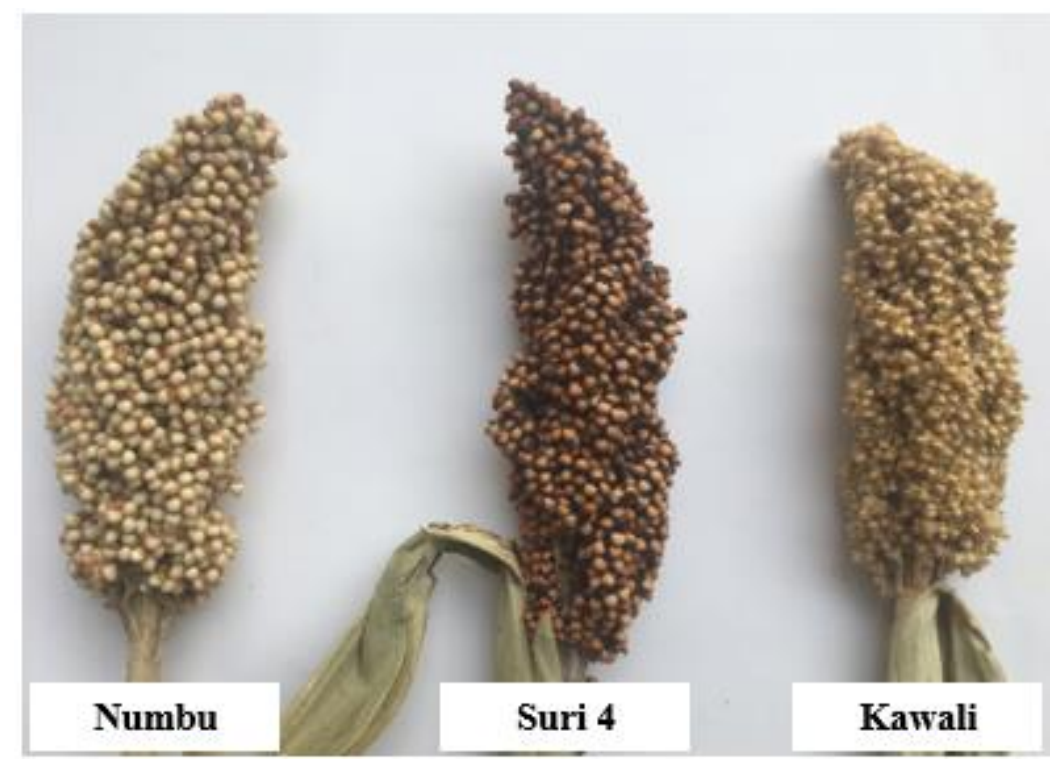

Gambar 2. Malai varietas Numbu, Suri 4 dan Kawali

Umur berbunga berkorelasi erat dengan umur panen. Semakin cepat umur berbunga maka umur panen biasanya juga akan semakin cepat. Jika dilihat dari umur berbunga, maka varietas Suri 4 adalah varietas yang paling sesuai dikembangkan di Wilayah Kediri. Masa panen Varietas Suri 4 yang cepat sesuai untuk ditanam di lahan marginal pada puncak musim kemarau. Pengamatan umur panen menunjukkan pengaruh yang nyata. Varietas Suri 4 memiliki umur panen yang paling cepat dibandingkan dengan varietas lainnya. Hal ini sesuai dengan umur berbunga, dimana Varietas Suri 4 juga memiliki umur berbunga yang paling cepat. Umur panen Varietas Suri 4 sesuai dengan deskripsi 
varietasnya. Sedangkan untuk Varietas Kawali dan Numbu, umur panen ternyata lebih cepat dibandingkan dengan deskripsi. Hal ini dimungkinkan karena penelitian dilaksanakan pada puncak musim kemarau di Wilayah Kediri, dengan intensitas penyinaran matahari dan suhu yang lebih tinggi dibanding dengan tahun-tahun sebelumnya. Sehingga pemenuhan heat unit tanaman sorgum lebih cepat tercapai dan mempercepat masa panen.

Kebutuhan benih per hektar dapat diperkirakan dengan menggunakan berat 1000 biji. Berat 1000 biji juga merupakan salah satu komponen hasil yang perlu diketahui karena menggambarkan kemampuan suatu genotip tanaman dalam memproduksi biji yang baik dan berkualitas. Hasil analisis menunjukkan perbedaan nyata pada pengamatan berat 1000 biji. Varietas yang mampu menyediakan lebih banyak benih adalah Varietas Suri. Sedangkan Varietas yang memiliki kemampuan paling sedikit dalam menyediakan benih adalah Varietas Numbu. Hal ini terlihat dalam kenampakan fisik biji masing - masing varietas.

Biji Varietas Numbu memiliki ukuran yang paling besar dibandingkan dengan varietas yang lain sehingga memiliki berat 1000 biji yang paling besar. Sedangkan biji Verietas Suri memiliki bentuk yang berongga sehingga walaupun terlihat besar, namun memiliki berat yang paling ringan

Malai tanaman sorgum dipanen ditandai dengan daun bendera yang telah menguning dan biji pecah apabila ditekan dengan jari. Panjang malai sorgum setiap varietas berbeda walaupun tanaman di tanam pada lahan yang sama. hasil analisis panjang malah menunjukkan hasil yang berbeda nyata. Pada penelitian ini panjang malai yang optimal ditunjukkan oleh Varietas Kawali dan Suri. Namun kedua varietas ini memiliki bentuk malai yang ramping. Varietas Numbu memiliki panjang malah yang lebih pendek dibanding varietas lain namun memiliki bentuk malai yang lebih berisi (Gambar 2).

Hasil pengamatan berat malai memiliki pengaruh yang berbeda nyata. Varietas Numbu dan Suri 4 memiliki berat malai yang lebih berat dibanding dengan Varietas Kawali. Perbedaan berat malai bisa terjadi karena perbedaan varietas sesuai dengan taraf pertumbuhannya. Karena distribusi bahan kering ke batang, daun dan biji lebih dipengaruhi oleh faktor genetik dibanding faktor lingkungan.

Berat pipilan per tanaman merupakan salah satu indikator dalam mengukur daya hasil suatu varietas tanaman. Berat pipilan per tanaman juga digunakan sebagai dasar perhitungan potensi hasil tanaman sorgum. Salisbury \& Ross (1995) menyatakan bahwa pembentukan dan pengisian biji sangat ditentukan oleh kemampuan genetik tanaman yang berhubungan dengan sumber asimilat dan tempat penumpukannya pada tanaman. Hasil analisis berat pipilan per tanaman menunjukkan hasil yang berbeda nyata. Varietas Suri 4 memiliki berat pipilan paling tinggi jika dibandingkan dengan varietas lainnya, disusul Varietas Numbu. Berat pipilan per tanaman paling rendah adalah pada Varietas Kawali.

Potensi hasil, adalah prakiraan hasil yang akan diperoleh jika tanaman sorgum ditanam dalam satu hektar.
Potensi hasil dihitung dari berat pipilan per tanaman dikali populasi dalam satu hektar. Hasil analisis potensi hasil menunjukkan adanya perbedaan yang nyata pada potensi hasil tiap varietas. Varietas yang memiliki potensi hasil paling tinggi adalah Varietas Suri 4. Sedangkan varietas yang memiliki potensi hasil paling rendah adalah Varietas Kawali. Rataan potensi hasil tiap varietas di atas angka 5 ton/ha. Hal ini menunjukkan bahwa potensi hasil tanaman sorgum yang ditanam di Wilayah Kediri jauh lebih tinggi dibanding dengan penelitian lain.

Penelitian Sutrisna (2013), terhadap beberapa varietas sorgum di lahan kering di Kabupaten Ciamis memperlihatkan bahwa produktivitas sorgum Varietas Kawali dan Numbu hanya sebesar 3,92 ton/ha dan 4,12 ton/ha. Produktivitas ini jauh lebih rendah dibanding dengan hasil penanaman sorgum dengan varietas yang sama di Wilayah Kediri. Banyak hal yang mempengaruhi perbedaan potensi hasil ini, antara lain kesesuaian lahan, metode pemupukan atau ketersediaan air. Jika hasil penanaman sorgum di Wilayah Kediri lebih tinggi, diduga kesesuaian lahan di Wilayah Kediri adalah S1.

\section{KESIMPULAN}

Seluruh varietas sorgum sangat sesuai untuk ditanam di Wilayah Kediri. Varietas sorgum yang tahan kekeringan, berdaya hasil tinggi dan memiliki potensi hasil yang maksimal dilihat dari berbagai parameter pengamatan yang dilakukan adalah Varietas Suri dan Varietas Numbu.

\section{UCAPAN TERIMA KASIH}

Ucapan terima kasih ditujukan kepada Universitas Islam Kadiri (UNISKA) Kediri yang telah mendukung terlaksananya penelitian ini berkat pemberian dana penelitian hibah internal tahun anggaran 2019. Terima kasih ditujukan pula kepada Fakultas Pertanian UNISKA yang telah memberikan sarana dan prasarana yang sangat membantu pelaksanaan penelitian.

\section{DAFTAR PUSTAKA}

Ariani, M. \& Ashari (2003). Arah, kendala dan pentingnya diversifikasi konsumsi pangan di indonesia. Forum Penelitian Agro Ekonomi, 21(2).

Balitsereal. (2017). Deskripsi Varietas Sorgum. http://balitsereal.litbang.pertanian.go.id/varietassorgum/

Human, S. (2011). Riset \& Pengembangan Sorgum Dan Gandum Untuk Ketahanan Pangan. Pusat Aplikasi Teknologi Isotop dan Radiasi Badan Tenaga Nuklir Nasional (BATAN). Jakarta Selatan

Elizabeth, R. (2011). Strategi Pencapaian Diversifikasi dan Kemandirian Pangan: Antara Harapan dan Kenyataan. Iptek Tanaman Pangan, 6(2). 
Fikri, M.N. ; Zuhry, E. \& Nurbaiti. (2015). Uji Daya Hasil dan Mutu Fisiologis Benih Beberapa Genotipe Sorgum Manis (Sorghum bicolor (L.) Moench) Koleksi BATAN. JOM Faperta 2(1)

Salisbury, F.B \& Ross, C.W. (1995). Plant Physiology, Thirth Edition. Wadsworth Publishing Company Belmont. California.540p

Sirappa, M. P. (2003). Prospek pengembangan sorgum di indonesia sebagai komoditas alternatif untuk pangan, pakan, dan industri. Jurnal Litbang Pertanian, 22(4).

Subagio, H. \& Aqil, M. (2014). Perakitan dan Pengembangan Varietas Unggul Sorgum. Iptek Tanaman Pangan, 9(1).

Sutrisna, Nana. (2013). Juknis Usaha Tani Sorgum. Balai Pusat Pengkajian Teknologi Jawa Barat 